\title{
INTRODUCTION TO HUGOYE 13: A DOUBLE ISSUE ON PHILOXENOS OF MABBUG
}

\author{
DAVID A. MiCHELSON
}

UNIVERSITY OF ALABAMA

From his birth in Persia to his exile and death in Thrace (523), the life and work of the fifth-century bishop Philoxenos of Mabbug

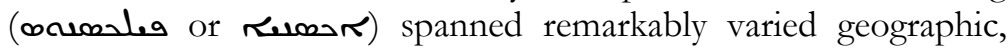
political, and religious environments. ${ }^{1}$ Perhaps originally educated as a dyophysite in Edessa, Philoxenos eventually became the miaphysite metropolitan of Mabbug (Hierapolis in Euphratensis). Active in the ecclesiastical politics of Antioch and Constantinople, Philoxenos also strategically used his location on the Euphrates to engage in missionary activity beyond the Roman Frontier both in Persarmenia and Arabia. Over the course of his ecclesiastical career, Philoxenos played the many roles of an experienced bishop: ascetic leader, theologian, exegete, patron of a revised Syriac New Testament, polemicist, and would-be imperial counselor. Philoxenos wrote prolifically leaving works in a variety of genres: polemics, Biblical commentary, homilies, doctrinal theology, letters, and ascetic paranaesis. In a few cases even, first or second hand manuscript copies of these works have survived from the early sixth century.

In spite of such a diverse career and voluminous source materials, Philoxenos remains relatively unknown to historians and

${ }^{1}$ I would like to thank my co-guest editor, Robert Kitchen, and also George Kiraz and the Hugoye editorial board for their assistance, encouragement, and patience in assembling this issue of Hugoye. 
theologians studying late antiquity, and at times has been neglected even by those working in Syriac. This thematic double issue of Hugoye dedicated to Philoxenos is a hopeful indicator that the tide of scholarly interest is now turning. Many of the articles here are the fruits of a symposium which brought together several scholars who had each been working on Philoxenos more or less independently. We hope that bringing these studies together in print will spark even further scholarly interest in Philoxenos.

One of the obstacles faced by this current florescence of Philoxenian scholarship is the need to reconceptualize the man and his oeuvre. The two major interpreters of Philoxenos in the twentieth century, Joseph Lebon and André de Halleux, have long called scholars to move beyond the traditional "heretical" interpretation of the bishop. One of the greatest deficiencies resulting from this long stereotyped view of Philoxenos is that he has existed, if at all, primarily as a monophysite foil in the larger literature on late antiquity. Such a negative assessment of Philoxenos has a long pedigree. Already in 523, at the time of his death, Philoxenos was alternately revered and reviled by those who commented on his life.

This opprobrium, mutatis mutandis, persisted in the earliest of modern accounts of Philoxenos, that of J.S. Assemani. As is the case with all of the interpreters of Philoxenos mentioned here, we owe more than we can calculate to their pioneering efforts. Assemani's treatment of Philoxenos was the first modern assessment and for some of Philoxenos' works still provides the only edited editions of certain texts. Nevertheless, Assemani's assessment of Philoxenos has left two legacies to subsequent scholarship; both of which in their own way have led to a wooden view of Philoxenos and to a tension in our understanding of his influence. Assemani's interpretation is best summed up in two comments: "Scelestissimum haereticum... Scripsit Syriace, si quis alius elegantissime..."2 Thus in Assemani's account we have two poles, Philoxenos the ardent or most committed of "monophysites" and Philoxenos the beacon of Syriac literature between the ages of Ephrem and Jacob of Edessa.

2 J.S. Assemanus, Bibliotheca Orientalis Clementino-Vaticana, II (Rome, 1719), 2: 11, 20. 
Certainly Assemani's initial introduction of Philoxenos was not without some grounds at least in its observation of Philoxenos' commitment to miaphysitism and his place in Syriac letters (though one might disagree with the strength or theological conclusions of Assemani's assessments). The danger arises from the fact that these two observations remain all that is generally known of Philoxenos. Thus in Frend's Rise of the Monophysite Movement these two become fused as "The harsh, puritanical views of...Philoxenos... [which] represented the outlook of what was becoming a distinctly Syriacspeaking Monophysitism." 3 This complete identification of Philoxenos with his miaphysite Christology has found unconscious support in other works, even those who sought to view Philoxenos from a sympathetic position. For example in Roberta (Chesnut) Bondi's study, Philoxenos is presented in negative contrast (perhaps unconsciously) to the moderate Jacob of Serug and the sophisticated Severus. ${ }^{4}$

While the contours of Assemani's Philoxenos persist in the scholarly literature, Philoxenos has not remained without a sympathetic and nuanced interpreter. The work of André de Halleux, both textual and historiographic, has served as the foundation for almost all work on Philoxenos since the 1960s. Under the pen of De Halleux, Philoxenos emerged as an adept ecclesiastical politician and a prolific author responding to a range of the pressing issues of his day. De Halleux's primary aim was to reveal the outlines of Philoxenos' "génie intuitif" and to explain the simple (anti-scholastic) nature of Philoxenos' understanding of the incarnation. De Halleux's Philoxenos is a portrait whose accuracy continues to be confirmed by further research. Nevertheless, it is important to bear in mind the centrality of Christology to De Halleux's own account. We may take as an example his concluding remarks which seem to equivocate, both emphasizing that "it remains legitimate to confirm the deep agreement between the Christology of Philoxenos and that of the council which he rejected with his whole soul [Chalcedon]" and yet noting that "our theologian occupied, according to all the evidence, an extreme

3 W.H.C. Frend, The Rise of the Monophysite Movement: Chapters in the History of the Church in the Fifth And Sixth Centuries (Cambridge, 1972), 185.

4 R.C. Chesnut, Three Monophysite Christologies: Severus of Antioch, Philoxenus of Mabbug, and Jacob of Sarug (Oxford, 1976). 
position." 5 In short, De Halleux's task was one of rapprochement and perhaps even rehabilitation. ${ }^{6}$ Given previous disparaging approaches to Philoxenos, this corrective was desperately needed. The question for us, as as the beneficiaries of De Halleux's labors, is to ask which directions will be most fruitful for future research to turn. In this regard, we may find it useful to turn from De Halleux's conclusion to his avant-propos, where he wrote: "We present these pages to the reader as an interpretive essay, inviting him to verify them and as needed to correct our conclusions with even greater and deeper inquiries."

Using his invitation as a point of departure, I would like to suggest that we need not merely repeat De Halleux's efforts to "rehabilitate" Philoxenos. Specifically, we can now benefit most from approaching Philoxenos from perspectives other than the Christological disputes. This is not by any means to suggest that we ignore Christology but rather to put Philoxenos' involvement in the Chalcedonian conflicts within the full context of his ecclesiastical career. A "holistic" approach to Philoxenos will ultimately serve us well in understanding not only this prolific Syriac churchman, but also allow his career and works to provide us with a nuanced and complex window onto many of the perennial questions of late antique scholarship.

In short, my argument is that we need to recover Philoxenos as more than just a "monophysite" polemicist. This aim requires that we raise new questions: How can we conceive of Philoxenos as a theologian of miaphysite sympathies without allowing those sympathies to define him? How can we situate Philoxenos, the Syriac bishop, within the broader cultural and linguistic milieu of the empire of Anastasius, of the patriarchate of Antioch, and of the Persian frontier, without conceiving him solely as a forerunner of a later Syrian Orthodox trajectory? How do we approach Philoxenos

5 André de Halleux, Philoxène de Mabbog. Sa vie, ses écrits, sa théologie (Louvain, 1963), 514.

${ }^{6}$ De Halleux's task is perhaps analogous to that of Pauline Allen and C.T.R. Hayward in Severus of Antioch (New York, 2004), cf. 32-4. Note, however, that while Allen and Hayward raise the level of analysis for Severus, in their passing mention Philoxenos remains "the militant antiChalcedonian bishop" (8).

${ }^{7}$ De Halleux, Philoxène, viii-ix. 
as one late antique churchman and ascetic theologian among many, and interpret him in terms of broader trends of late antique Christianity? Conversely, how can we use Philoxenos to learn about late antique Christianity writ large, not just as a case study in miaphysite dogmatism or the particulars of the Syriac tradition?

It is the hope of the editors that the articles offered here, by promoting current research on Philoxenos, will be a step toward reintroducing Philoxenos into the larger narratives of late antique religion and culture. As noted above, most of the articles in this issue and in the subsequent issue yet forthcoming originated from a one day symposium, "Reconsidering Philoxenos of Mabbug" held May 8, 2008 at the Center of Theological Inquiry, Princeton, New Jersey and organized by Robert Kitchen and David Michelson. Sponsorship for the symposium came from the Center of Theological Inquiry, Gorgias Press, and Princeton University (including the following units: Center for the Study of Religion, Group for the Study of Late Antiquity, and the Program in Hellenic Studies). A fuller report on this symposium is found in this issue.

In the pages that follow, we offer three articles and an extended review of a revised translation of Philoxenos' Discourses to be followed in the next issue of Hugoye by an additional three articles and a bibliographic clavis. The first article in the present issue addresses what has perhaps been the longest running question of scholarly interest in Philoxenos, the nature and text of the Philoxenian New Testament. Daniel King, in "New Evidence on the Philoxenian Versions of the New Testament and Nicene Creed in the Context of the History of Greco-Syriac Translations" recalibrates the position of Philoxenos in the chronology of Greek to Syriac translation. Drawing on evidence from the Syriac translations of Cyril which predates Philoxenos, King argues that earlier fifth-century experiments in translation had a formative influence on Philoxenos' as a theologian and reader of the Greek patristic authors. King concludes that it is to this earlier generation of translators which we may attribute the beginnings of the "mirror" style translation, a method continued by the translators of the Philoxenian New Testament.

The second article, by Fr. Roger-Youssef Akhrass considers Philoxenos as a theologian of the Theotokos. Specifically, Akhrass identifies the symmetrical role between the virgin birth and the 
eternal generation of the Son in Philoxenos' doctrine of the incarnation. While this observation adds further to our understanding of Philoxenos' appeals to the title Theotokos in his polemics, it is equally important for understanding Philoxenos as a constructive theologian in his own right. In short, through Philoxenos' theology of Christ's virginal conception we catch a glimpse of the inner workings of his Christology.

The third article and a review essay, both by Robert Kitchen, take up the other part of the Philoxenian opera to have received considerable scholarly debate: Philoxenos' thirteen ascetic Discourses. In "The Lust of the Belly is the Beginning of All Sin: A Practical Theology of Asceticism in the Discourses of Philoxenos of Mabbug," Kitchen draws on comparisons with the Book of Steps to propose a new interpretive framework for the ascetic system found in the Discourses. Specifically, Kitchen argues that Philoxenos saw the defeat of gluttony as a boundary line which distinguished the untrained novice monk (the upright) from the seasoned ascetic on the path of perfection. Kitchen, who is preparing a revised English translation of the Discourses, also reviews the recent revised translation of the Discourses by René Lavenant in the Sources Chrétienne. Kitchen rightly notes the long running interest this text has generated among scholars as one of the few Syriac texts to have appeared in multiple translations.

The articles offered in this issue are but the initial steps toward a new scholarly reconsideration of Philoxenos. While they treat topics which have long been debated, they reveal the fecundity of the Philoxenian sources for future research. Moreover, these articles make at least initial progress towards a more holistic approach to Philoxenos, acknowledging other influences on Philoxenos' thought besides Christological controversy. May this issue of Hugoye and its forthcoming counterpart provoke further consideration of this prolific and influential Syriac churchman. 